\title{
Current Research Trends on Improvement of Balloon Flower Production and Processing
}

\author{
Shin-Woo Lee ${ }^{1}$, Young-Son Cho ${ }^{1}$ and Yong-Wook Shin ${ }^{1,2 *}$ \\ ${ }^{1}$ Dept. of Agronomy \& Medicinal Plant Resources, Gyeongnam National University of Science and Technology, Jinju 660-758, Korea \\ ${ }^{2}$ International Garden Institute, Gyeongnam National University of Science and Technology, Jinju 660-758, Korea
}

$$
\begin{gathered}
\text { 도라지의 생산과 가공 향상에 관한 최신 연구 동향 } \\
\text { 이신우 }{ }^{1} \text { - 조영손 }{ }^{1} \text { - 신용욱,2* } \\
{ }^{1} \text { 경남과학기술대학교 농학· 한약자원학부, }{ }^{2} \text { 경남과학기술대학교 국제정원연구소 }
\end{gathered}
$$

\begin{abstract}
Balloon flower (BF, Platycodon grandiflorum (Jacq.) A.DC.) is a monotypic species of the bellflower family (Campanulaceae), which is native to Asia. In terms of popular culture of east asian country, BF has been in the limelight as flowers, medicine and food. Platycosides (saponins) from the roots of BF are reported to have a wide range of efficacy and characterized by a structure containing a triterpenoid aglycone and two sugar chains. Saponins from BF are of pharmaceutical significance, and their applications are increasing with evidence of their efficacy. As the cultivation area of BF is continually increased in Korea, research for preventing root rot incidence and nitogen fertilizer application on yield of saponin are reported and also storaging, steam heating and bio-transformational method are developed. There are several biological effects of compounds from BF. saponin from BF has cholesterol lowering effects, neuroprotective activity, cytotoxic effects against cancer cells, and polysaccharide has immuno-boosting effects and pheolic compounds from aerial part of BF has anti-oxidative effects. However, The purchase decision factor of consumers in market is cultivate year of BF and producing country are also important as contents of platycodins in BF. This paper reviews the origin of plants, harvest and post harvest processing methods that maximize the value in terms of efficacy of extracts and platicoside from BF.
\end{abstract}

Key words: Biological effect, Platycodon grandiflorum, Platycoside, Saponin

\section{I . Introduction}

Balloon flower (BF, Platycodon grandiflorum (Jacq.) A.DC.) is a monotypic species of the bellflower family (Campanulaceae), which is native to Asia, the BF has been in the limelight as flowers, medicine and food. In Japan, traditionally, it have been loved one of the 'Seven Autumn Flowers', and became a crest (Kamon) of several clans. In China, it is used in traditional Chinese medicine. And in Korea, the root has been used as a popular ingredient in salads and traditional cuisine.

$\mathrm{BF}$ is a bushy, clump-forming perennial, to 3 feet tall, but

Received on November 26, 2014. Revised on December 22, 2014. Accepted on December 24, 2014.

*Corresponding author: ywsynn@gntech.ac.kr

본 논문은 농촌진흥청 공동연구사업(PJ008801)의 지원에 의하여 이루 어진 것임. often troubled by floppy stems. Cultivars have been bred for smaller size and compact habits throughout July and August, the tumescent buds burst open to blue, pink, or white starry flowers streaked with prominent veins. In terms of landscape and gardening, especially western country, BF are as easy to grow as daylilies, which are probably the most reliable blue bloomers and added benefit, flowering peaks in mid-to-late summer. Cut them in the bud stage, they make great cut flowers. However, in Asian country, BF root used as a cough suppressant and expectorant for common colds, cough, sore throat in folk medicine. Through recent scientific research, its medicinal effect has been improved such as antiallergy, neuroprotective, anti-inflammatory, anti-obesity Antidiabetic and anti-cancer properties.

Identification of these various pharmacological action 


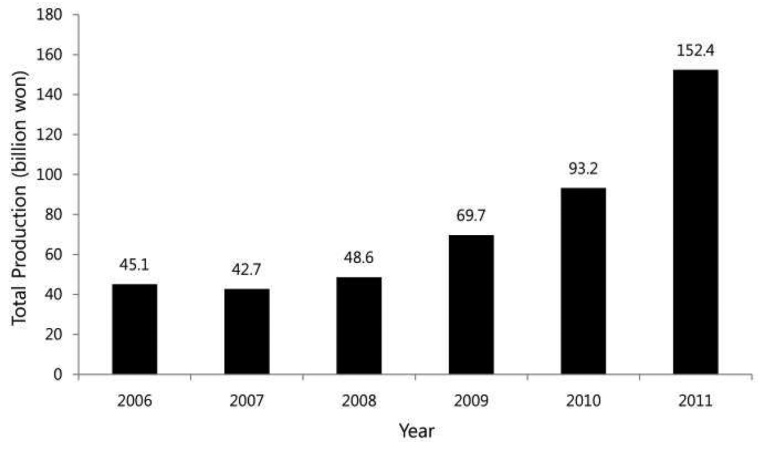

Fig. 1. The total production amount of Platycodon grandiflorum's root from 2006 to 2011 in south Korea (Lee et al. 2014).

causes a change in the production volume of BF. In South Korea, since 2006, the total production of volume of BF has been gradually increased and finally in 2012, it was produced an amount of 2.5 folds as in 2006 did (Fig. 1). In China, the largest exporter of $\mathrm{BF}$, due to the increase of its own domestic demand, export volume for Korea was decreased in around 2010. Meantime, the imported root of BF for the pharmaceutical purpose was 429 ton in 2001 but it has been dramatically decreased to 36 ton in 2011. Instead, the imported volume of dried or fresh one for food was 11,652 ton in 2008 and remained at similar level up to now.

Recently, the cultivation area is continually increased in Korea, especially in Gyeoungnam province. Because of consumer's continuous demands and a rising unit price, these trend will be continue for the time being (Lee et al, 2014). The reason of above is, there are sharply increase in the prevalence of chronic respiratory disease and lifestyle-related diseases due to lack of exercise and air pollution. meantime, saponin from root of BF have anti-asthmatic and cholesterol-lowering effect, which is need to take a long period, regardless of the form of food or drugs. Thus, this paper reviews the origin of plants, harvest and post harvest processing methods that maximize the value, in terms of efficacy of Extracts and platicoside from BF.

\section{Major contents of $\mathrm{BF}$}

\section{Saponin}

Triterpenoid saponins with an oleanene backbone were known as the main chemical constituents of BF. From now on more than 30 kinds of saponin components are founded (Choi

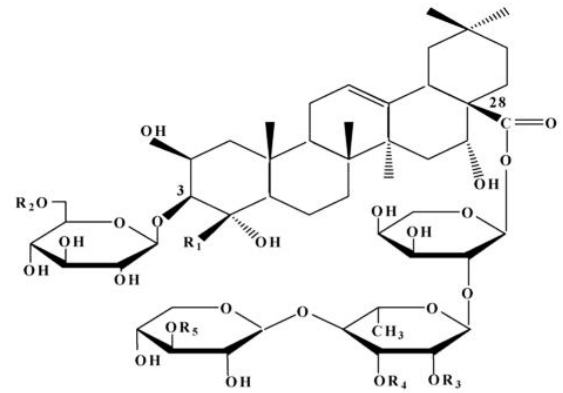

\begin{tabular}{clccccccc}
\hline No. & Platycoside & $\begin{array}{c}\text { Molecular } \\
\text { formular }\end{array}$ & MW & R1 & R2 & R3 & R4 & R5 \\
\hline 1 & Deapi-Platy coside E & $\mathrm{C}_{64} \mathrm{H}_{104} \mathrm{O}_{34}$ & 1416 & $\mathrm{OH}$ & $\mathrm{Gen}$ & $\mathrm{H}$ & $\mathrm{H}$ & $\mathrm{H}$ \\
2 & Platycoside E & $\mathrm{C}_{69} \mathrm{H}_{112} \mathrm{O}_{38}$ & 1548 & $\mathrm{OH}$ & $\mathrm{Gen}$ & $\mathrm{H}$ & $\mathrm{H}$ & Api \\
3 & Deapi-Platy codin D3 & $\mathrm{C}_{58} \mathrm{H}_{94} \mathrm{O}_{29}$ & 1254 & $\mathrm{OH}$ & $\mathrm{Glc}$ & $\mathrm{H}$ & $\mathrm{H}$ & $\mathrm{H}$ \\
4 & Platycodin D3 & $\mathrm{C}_{63} \mathrm{H}_{102} \mathrm{O}_{33}$ & 1386 & $\mathrm{OH}$ & $\mathrm{Glc}$ & $\mathrm{H}$ & $\mathrm{H}$ & Api \\
5 & Deapi-Platy codin D & $\mathrm{C}_{52} \mathrm{H}_{84} \mathrm{O}_{24}$ & 1092 & $\mathrm{OH}$ & $\mathrm{H}$ & $\mathrm{H}$ & $\mathrm{H}$ & $\mathrm{H}$ \\
6 & Platycodin D & $\mathrm{C}_{57} \mathrm{H}_{92} \mathrm{O}_{28}$ & 1224 & $\mathrm{OH}$ & $\mathrm{H}$ & $\mathrm{H}$ & $\mathrm{H}$ & Api \\
7 & Polygalacin D & $\mathrm{C}_{57} \mathrm{H}_{92} \mathrm{O}_{27}$ & 1208 & $\mathrm{H}$ & $\mathrm{H}$ & $\mathrm{H}$ & $\mathrm{H}$ & Api \\
8 & 3"-O-acetyl polygalacin D & $\mathrm{C}_{59} \mathrm{H}_{94} \mathrm{O}_{28}$ & 1250 & $\mathrm{H}$ & $\mathrm{H}$ & $\mathrm{H}$ & Ac & Api \\
9 & Platycodin A & $\mathrm{C}_{59} \mathrm{H}_{94} \mathrm{O}_{29}$ & 1266 & OH & H & Ac & H & Api \\
10 & 2"-O-acetyl polygalacin D & $\mathrm{C}_{59} \mathrm{H}_{94} \mathrm{O}_{28}$ & 1250 & H & H & Ac & H & Api \\
\hline
\end{tabular}

Fig. 2. Structure of platycosides. Gen, glucose-glucose; Glc, glucose; Api, apiose; Ac, acetyl (Ha et al. 2006).

et al. 2008b) and 10 major triterpenoidal saponins have been idenfied (Fig. 2). Triterpenoid and steroidal glycosides are referred to collectively as saponins. They have considerable potential as pharmaceutical and/or nutraceutical agents from a variety of natural sources, and have been shown to have hypocholesterolemic, anti-coagulant, anticarcinogenic, hepatoprotective, hypoglycemic, immuno-modulatory, neuroprotective, anti-inflammatory and anti-oxidant activity (Rao and Gurfinkel, 2000). Triterpene saponins with inhibitory activity of glucose absorption may also be used for the prevention and treatment of diabetes. In addition, oleanolic acid glycosides showed other various medicinal effects such as antiallergic, antiinflammatory, antinociceptive, antipruritive, and gastroprotective effects and acceleration of small intestinal transit (Yoshikawa and Matsuda, 2000).

\section{Non saponin}

Phenylpropanoids (PPs) is as a secondary metabolites produced by plants, the molecular basis for the protective action of PPs in plants is their antioxidant and free radical scavenging properties. It has been medicinal use as antioxidant, UV screens, anticancer, anti-virus, anti-inflammatory, wound healing, and antibacterial agents (Korkina, 2007). The phenolic esters found in plants are related to the main functions of 
suberin and cuticle as a hydrophobic transport barrier against water loss over the plantsurface and as a protectant from pathogens or environmental harm. Their role as a physical barrier, these lipophilic plant surface layers are also important as a protectant from oxidation. Lee et al. (2004b) reported that two PPs isolated BF root are supposed to originate particularly from the suberin of the root have antioxidant activities. Chung et al. (2012) reported that ethyl acetate extracts of BF, fraction of rich phenolic compound, significantly reduced plasma and hepatic lipid levels in the high fat diet induced obse mice, by decreasing oxLDL-induced cell death and lactate dehydrogenase.

Lee et al. (2004a) reported that the petroleum ether fractioned phenolic compound, polyacetylene compound of $\mathrm{BF}$ was confirmed to exhibit antioxidant and anticancer activities. Jeong et al. (2010) reported that the butanol fraction of the aerial parts of $\mathrm{BF}$ has strong antioxidant activities that are correlated with its phenolic compounds, particularly luteolin-7O-glucoside and apigenin-7-O-glucoside. Jang et al. (2010) reported that flavonoids and caffeoylquinic acids, isolated from an EtOAc-soluble fraction of the flowers of BF have inhibitory activity on the formation of advanced glycation end products and rat lens aldose reductase in vitro

\section{Production and Processing of $\mathrm{BF}$}

\section{Origin of plant and quality evaluation}

Gyeongsangnam-do, Korea setting a rules governing preservation and promotion of indigenous balloon flower. Kim et al.(2014) established a technique to differentiate the indigenous balloon flower germ lines with those collected from South Korea and China, to develop RAPD analyses with five different primers exhibited high frequency of polymorphic DNA bands up to $76.9 \%$ and phylogenetic tree indicated that some of the indigenous lines can be easily differentiated with others. Park et al. (2005) also analyzed the genetic variation, genetic relationship of BF sample from East-Asia by means of RAPD-PCR markers. Geographically it was divided into 3 different cluster, but inconsistent group also existed, collected from China but they clustered to the same group collected from Korea. Park et al. (2010a) reported that the correlation of character of aerial parts on $\mathrm{BF}$ and content of platycodin

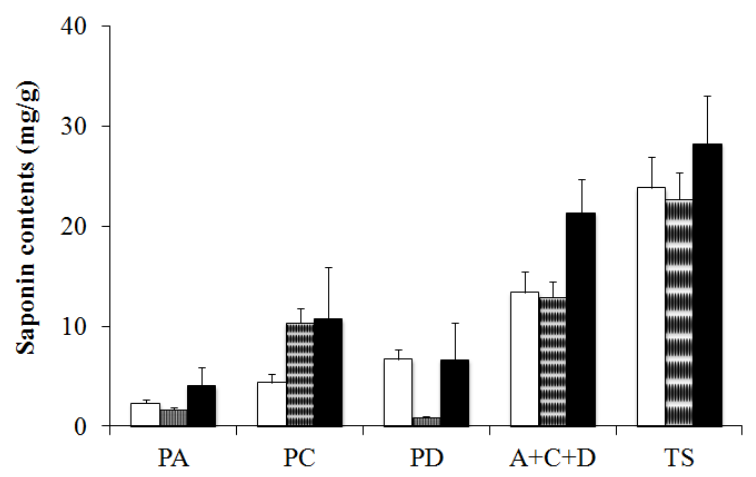

Fig. 3. Saponin contents $(\mathrm{mg} / \mathrm{g})$ of the $B F$ from different country. $\square: B F$ from China, $\square$ : BF from Korea, $\mathbf{\square}$ : BF from Japan, PA:Platycodin A,PC: Platycodin C,PD: Platycodin D, TS: Total saponin (Data from Saeki et. al., 1999, 2003).

$\mathrm{D}(\mathrm{PD})$. PD was represented highly negative correlation coefficients between plant height, stem diameter, leaf length, root diameter, and root weight. Among the collected resources, PD content of Japanese collections, which is a main medicinal property in $\mathrm{BF}$, was higher than the Chinese and Korea collections. Kim et al. (2007) revealed that Korean BF (esp. 21 years old) contained more deapioplatycoside $\mathrm{E}$, platycoside $\mathrm{E}$, deapioplatycodin $\mathrm{D}$ 3, platycodin $\mathrm{D} 3$, polygalacin $\mathrm{D}$ 2, platycodin D2 than Chinese BF but had less than half the amount of PD compared to its Chinese counterpart. Because $88 \%$ Saponin of Chinese BF is PD, Yan YZ et al. (2012) demonstrated that saponin content of $\mathrm{BF}$ is determined by its petal color and geographical location. The accessions with blue flowers dominated over those with white one. especially, PD.

$\mathrm{BF}$ with white petal is native to Korea. However, compared to root of BF with white petal, sanpoin from those of blue petal are more distributed in cortex of root (Shin and Kang, 1992).

The purchase decision factor of consumers in market, cultivate year and producing country are also important as contents of platycodins in BF. First of all, identification of the cultivation year of $\mathrm{BF}$ is very important in commercial market. Ahn et al. (2011) sugguested the criterion, that is, the characteristics of the cork layer, latex tube, and vessels were shown to be useful keys to confirm the cultivation year of BF. Second of all, Saeki et al. (1999) proposed a reference Platycodins to distinguish BF collected in three Northeast Asia countries. Briefly, BF from Korea, China and Japan has comparative advantage in platydodin $\mathrm{C}$, platycodin $\mathrm{D}$ and 


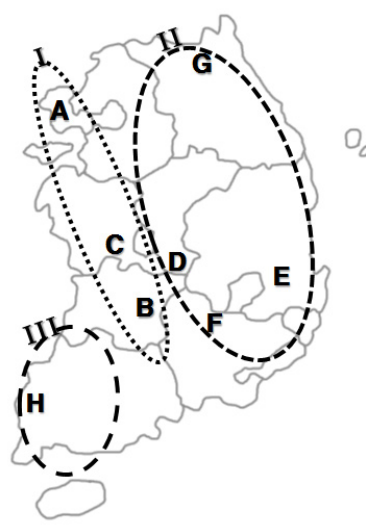

\begin{tabular}{ccccccccc}
\hline \multirow{2}{*}{ Saponin } & \multicolumn{3}{c}{ I } & \multicolumn{5}{c}{ II } \\
\cline { 2 - 9 } & A & B & C & D & E & F & G & H \\
\hline$\alpha$ & 2.32 & 1.43 & 2.68 & 1.51 & 1.21 & 1.77 & 1.72 & 3.35 \\
$\beta$ & 1.71 & 1.77 & 1.66 & 1.44 & 1.26 & 1.41 & 1.10 & 0.41 \\
$\gamma$ & 0.04 & 0.07 & 0.06 & 0.01 & 0.05 & 0.02 & 0.03 & 0.01 \\
\hline
\end{tabular}

Fig. 4. Clustering of the samples based on 3-platycoside content and geographical locations of the cultivated areas (Yoo et. al., 2011).

platycodin A, respectively (Fig. 3). You et al. (2011) determined with 18 platycosides for $\mathrm{BF}$ samples cultivated in eight different Korean provinces. Amongst these 18 platycosides, platycoside $E(\alpha)$ showed the highest content, followed by polygalacin D2( $\beta)$ and 3"-O-acetylplatyconic acid A( $\gamma)$. The sum of these three compounds was recommended for quality control of balloon flower root for medicinal purposes. And finally they clustered the samples into groups based on platycoside content. Group I, characterized by a high concentration of platycosides, was located near the west coast of Korea, whereas group II, characterized by a low concentration of platycosides, was located inland or in mountainous area(Fig. 4).

Triterpenoid saponins with unique chemical features on an oleanene backbone were known as the main chemical constituents of the species and more than 30 kinds of saponin components such as PD have been reported so far (Choi et al. 2008b). Nevertheless, Saeki and Nikaido (2003) suggested quantitative method, that is, Not only for Platycodins, including PA, PC, a PD but for the Polygalacin acids and Platycosides, was a index to evaluate $\mathrm{BF}$ for an effective means to the quality evaluation method.

\section{Cultivate}

Lee et al. (2013a) mentioned that, to optimizing for the
Table 1. Corelation coefficient between ridge width, furrow depth, and experimental period and Rhizome Rot incidence of Platycodon grandiflorurm (August 10-25, 2010) (Kim and Cho, 2011).

\begin{tabular}{cc}
\hline Elements & Rhizome rot incidence \\
\hline Ridge width $(\mathrm{m})$ & $0.88^{* *}$ \\
Furrow depth $(\mathrm{m})$ & $-0.75^{* *}$ \\
Experimental period (year) & $0.78^{* *}$ \\
${ }^{* *}$, significant at 0.01 probabilities. &
\end{tabular}

pre-seeding treatment on seed germination of $\mathrm{BF}$, germination rate of chilling period 1 week was higher than other treatment. Promptness index(PI) on at $25^{\circ} \mathrm{C}$ was higher than other temperature. Lee et al. (2000) reported that the data for the management of $\mathrm{BF}$ root rot syndrome showed the soil $\mathrm{K}, \mathrm{NH}_{4}$ $-\mathrm{N}$ content and $\mathrm{EC}$ value of injury root were higher than those of normal root. The root $\mathrm{CaO}$ content was positively correlated with yield. The Fe and $\mathrm{Zn}$ content of normal root were higher than those of injury root, while the T-N, $\mathrm{P}_{2} \mathrm{O} \_5$ and $\mathrm{K}_{2} \mathrm{O}$ content of normal root were lower than those of injury root. The population of bacteria, actinomycetes and bacteria/fungi ratio increased in soil of normal root, but that of fungi decreased. Kim and Cho (2011) reported that correlation on characteristics of Seedling place status and BF root rot incidence. that is, ridge width, soil water content, soil hardness, and cultivation period were positively related with Rhizome rot incidence, however, furrow depth was negatively related with that. So cultivation method should be developed such as making underground ditch or cultivation in well draining soil for escaping excess waster damage (Table 1).

Seong et al. (2004) reported that optimum nitrogen split application ratio of 50:50\% improve yield of saponin and quality BF. Lee et al. (2010) reported that Relationship between soil $\mathrm{pH}$ and $\mathrm{EC}$, content of exchange calcium in soils for $\mathrm{BF}$ cultivation. In brief, regarding chemical properties of soil, content of exchangeable calcium in soils from cultivation BF 3 more consequent years were showed 2 3 time higher level than average upland soil of Korea. Lee et al (1999) reported that the total crude saponin contents were decreased by increasing cultivating years. And they assumed that it because, as Root grows, the relative proportions of tail and cortex of root, which is saponin rich part, were reduced. However, the creating of giant BF by the polyploidy breeding 
method can maximize its efficacy. Because, in medicinal use, polyploidy may increase the amounts of secondary metabolites. Boo et al. (2013) conducted to obtain tetraploid to have higher contents of pharmaceutical constituents as well as higher yield in BF by colchicine treatment, and their antioxidant activity were compared with diploid. Han et al (2014) shows the way to prevent the occurrence of blue balloon flower in the massive cultivated area of white balloon flower by providing the seedlings raised from in vitro regenerated plants. It is reported that NAA was better than IBA for the induction of root and it took 16.9 days for the induction of rooting on the MS solid media containing $0.5 \mathrm{mg} / \mathrm{L}$ of NAA and the final rooting ratio was up to $75 \%$. And also choosing optimized bed soils for the acclimation and growth of in vitro regenerated balloon flower. On 8 weeks after planting of in vitro regenerated plants in pots containing. In the optimized bed soils, the plant hight was increased up to 2-fold , 3.5-fold for the number of leaf and 1.5 -fold for the leaf length.

\section{Post harvest processing}

A variety of techniques that can be influence directly on the content of saponin, such as storaging, blenching and puffing method, have been reported to influence the content of saponin for after harvest. Lee et al (2014a) reported that the high root hardness was significantly related with storing temperature and methods. During 50 days, platycodin D3 and polygalacin of BF which is storaged at room temperature was increased $16-25 \%$ than cold storaged one, but it shows a decreasing tendency of after 100 th days. And deapioplatycodin D showed a tendency to increase as the storaging period is longer.

Before convert $\mathrm{BF}$ into frozen food materials, blanching process are needed to prevent surface discoloration. Lee et al. (2011c) reported that $90^{\circ} \mathrm{C}$ for $1 \mathrm{~min}$ to be the most highly evaluated in terms of the Storage stability level include hardness, colorness and sensory characteristics. Puffing has induced a porous structure in $\mathrm{BF}$ so that the extraction yield increased by enhanced penetration of the extraction solvent into the inner portion. The changes of saponin components in BF by puffing process were reported (Park et al., 2012). Briefly, major changes in appearance were browning and volume expansion, which lead extraction yields and crude saponin yields increase
Table 2. The relative ratio of major platycosides after enzymatic reaction ( $\mathrm{Ha}$ et al., 2010)

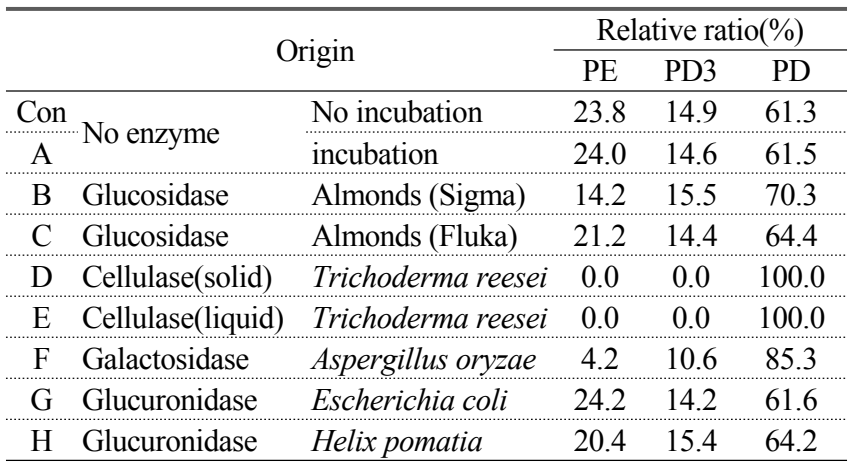

up to $21 \%$ and $41.6 \%$ respectively. The DPPH radical scavenging activity of puffed $\mathrm{BF}$ also increased three-fold.

Lee et al. (2013b) and Hwang et al. (2011) reported that correlation between heating and antioxidative effects was high. Lee et al. (2013c) assume that high molecular phenolic compounds and phenolic compounds which is bound to the protein was converted to low molecular phenolic compounds by heat treatment. This is due to conjugated phenolic compound of $\mathrm{BF}$ was transformed to the free phenolic compound, which is more low molocule, and finally increasing in a total phenolic amount, antioxidant activity increased consequently(Turken et al., 2005). And in addition, by-product of Mailliard reaction, have anti oxidative effect also (Kim et al., 1981). Lee et al. (2013d) reported that steamed BF (Black BF, steam dried $\mathrm{BF}$ ) showed a higher amount and extraction rate of saponin, almost twice as much crude saponin as BF did.

Ha et al. (2010) have achieved enzymatic conversion of platycosides to PD within $24 \mathrm{hr}$ utilizing cellulase from Trichoderma reesei, that is, cellulase, $\beta$-galactosidase, and $\beta$ -glucosidase are able to transform platycoside $\mathrm{E}$ and platycodin D3 into PD. PD was modified with a crude enzyme extract from Aspergillus niger. The modified PD possessed a shorter sugar side-chain, and presented a remarkably reduced cytotoxicity and hemolytic toxicity, whereas Sensory scores for pungency were improved (Wie et al., 2007)

\section{Major Efficacy of BF}

\section{Immune boosting Effects}

Park et al. (2010b) reported that BF has an immunogenicity 
effect as an adjuvant on adaptive immune system. That is, the proliferation of lymphocytes and the antibody titer were increased after BF treatment. The increased subisotypes of antibodies were $\mathrm{IgG} 2$ and $\mathrm{IgG} 3$ induced from T1-helper cells. Ryu et al. (2014) mentioned water extract from BF enhanced the immune function by regulating the splenocytes proliferation and cytokine production capacity by activating macrophages. Han et al. (2011) reported that enhancing immune system is due to polysaccharide isolated from BF. It's polysaccharide markedly specific activator of B cells and macrophages but not of $\mathrm{T}$ cells. It increase polyclonal IgM antibody production and the proliferation of B cells, and to activate iNOS transcription and NO production in macrophages. Takechi (1995) reported that $\mathrm{C}-3$ of aglycone could affect the haemolytic and adjuvant activities of platycodigenin-type saponins, and that PD had immunological adjuvant activity, and simultaneously elicited a Th1 and Th2 immune response by regulating gene expression of Th1/Th2 cytokines and transcription factors.

Vaccines require association with adjuvants capable of increasing the potency or stimulating the appropriate immune response. Saponins activate immune system, which has led to significant interest in their potential as vaccine. The lead saponin adjuvant is QS-21. However, the high toxicities and undesirable haemolytic effects of QS-21 have been pointed out as the main restriction to its use as adjuvant. Xie et al. (2008) reported that Platycodin D2 could be safely used as adjuvant eliciting Th1 and Th2 immune responses. Haemolytic activity for PD2 than Quil A, which is one of most predminant saponins in Quil A. As adjuvant potential on the cellular and humoral immune responses. PD2 significantly enhanced a specific antibody and cellular response against OVA in mice and modulated the quality of the immune responses resulting in a balanced immunity for broader protection. However, PD2 was showed to be less haemolytic effect than Quil A. Oda et al. (2000) reported that adjuvant activity of saponins does not relate with haemolytic activity.

\section{Immune modulating Effects}

Kim et al. (2012) reported that fermented BF by Lactobacillus plantarum (LP), up regulate Th1 cytokines, IL-12, p40 and IFN- $\gamma$ while the levels of the Th2 cytokines IL- 4 and 5 were down-regulated. Ha et al. (2014) reported that fermented with Saccharomyces cerevisae decreased the serum levels of Ig E, MDA and reducing Itching reactions in mouse. Oh et al. (2010) demonstrate that BF Ext. inhibits PMA + A23187 induced production of IL-6, PGD(2), LTC(4), $\beta$-Hexosaminidase and COX-2 protein. Choi et al. (2009) reported that aqueous extract from the root of BF (21 years old) reduced the OVA-induced upregulation of matrix metalloproteases activity as well as NF-kappaB nuclear translocation. And increased level of the immunosuppressive cytokine IL-10. Reduced thickness of the epidermis/dermis and dermal infiltration of inflammatory cells in the ears. BF also suppressed TNF- $\alpha$ /IFN- $\gamma$-induced mRNA expression and production of TARC in $\mathrm{HaCaT}$ cells (Choi et al., 2012).

Kim et al. (2010) reported that Only PD significantly suppressed prostaglandin E2 production in rat peritoneal macrophage. Althogh platycodin D3 and oleanolic acid showed no effect at the same concentrations. Oral treatment of $\mathrm{BF}$ suppressed $\mathrm{AD}$-like skin lesions according to the assessment of skin severity and epithermal thickness in the DNCB-treated $\mathrm{NC} / \mathrm{Nga}$ mice. This alleviation was further correlated with a reduction of elevated serum total IgE or cytokine mRNA in the BF-treated group compared (Park et al., 2012).

\section{Cholesterol lowering Effects}

Unfortunately, drug treatment of obesity despite short-term benefits, is often associated with rebound weight gain after the cessation of drug use, side effects from the medication, and the potential for drug abuse (Abdollahi et al., 2003). It has been reported that $\mathrm{BF}$ has an anti-obesity property that prevents mice fed a high-fat diet from becoming obese. BF contains saponin (pladicodins), triterpene (betulin), polysaccharides (inulin) and phytosterols, which may have a beneficial effect on metabolic diseases (Kwon et al., 2009).

The high fat diet caused obesity with fat storage and a reduction in small intestinal sucrase activity. Han et al. (2002) reported that antiobesity action by crude saponins of BF may be due to the inhibition of pancreatic lipase activity and prevent the reduction in small intestinal sucrase activity. Platycodins inhibit the activity of human acyl-Co enzyme A and interfere with the formation of cholesterol micelles (Zhao et al., 2006). 

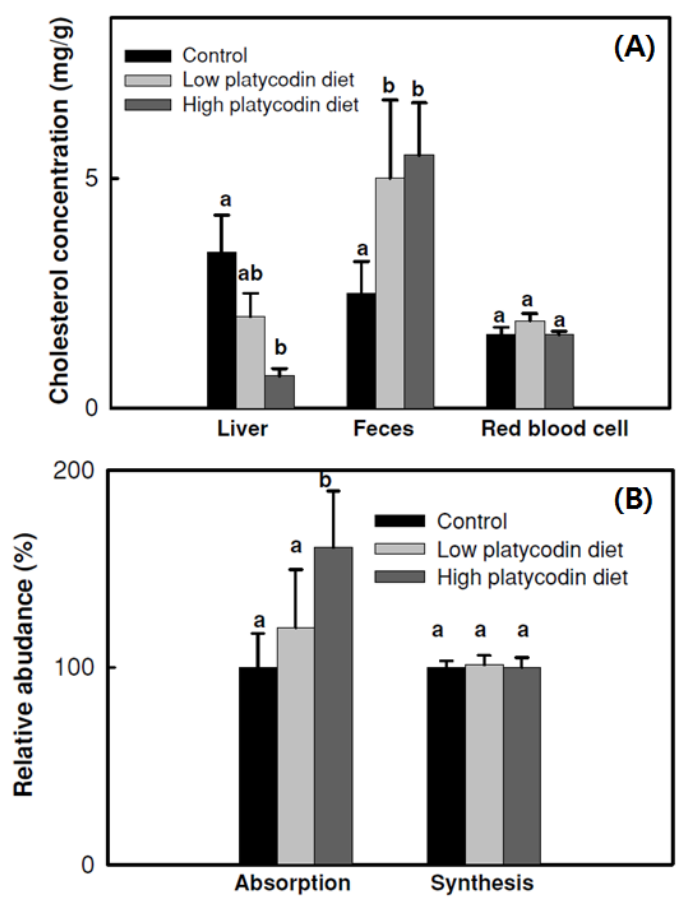

Fig. 5. Effects of platycodin intake on total cholesterol contents in liver, feces, and red blood cell (A), and fractional synthesis rate (B) (Zhao et al., 2008).

Platycodins also competitively inhibit pancreatic lipase (Han et al., 2000; Zhao and Kim, 2004; Xu et al., 2005), considered partly responsible for the reduction in dietary lipid digestion and intake (Zhao et al., 2006). Zhao et al. (2008) reported that Platycodins may play a role enhancing cholesterol excretion thus leading to reductions in plasma and hepatic cholesterol levels. Interestingly anti-obesity effect of platycodin suggests that reductions in body weights due to restricted food intake during the trial. This indicates that Body weight loss effect of $\mathrm{BF}$ is via central nervous system inhibitory action(Fig. 5).

And BF consumption likely increased fecal cholesterol excretion as fecal cholesterol concentration was increased up to 2.5 -fold. Cholesterol absorption increased in the animals receiving a high dose of platycodins that is platycodin feeding increased ( $\mathrm{P}<0.001)$ cholesterol absorption up to $60 \%$, it is assume that platycodins enhanced intestinal sterol permeability, resulting in increased cholesterol absorption, because saponins have been used to enhance trans-membrane permeability but not cholesterol synthesis. Han et al. (2000) reported that The aqueous extract of $\mathrm{BF}$ significantly reduced hepatic triacylglycerol concentrations and inhibit the intestinal absorption of dietary fat by inhibiting its hydrolysis. However Inulin, had no effect on the pancreatic lipase and fatty liver induced by the high fat diet. On the other hand, the total saponin fraction of the aqueous extract inhibited pancreatic lipase activity in vitro. Therefore, the antiobesity effect of the aqueous extract of BF may be due in part to the inhibition of intestinal absorption of dietary fat. Water extract of BF significantly repressed the up-regulation of FABP mRNA expression induced by a high-fat feeding in subcutaneous adipose tissue. Park et al. (2007) reported that water extract of BF inhibited 3T3-L1 pre-adipocyte differentiation and fat accumulation, and also decreased pancreatic lipase activity and plasma TC and TG concentrations. It indicates that BF not only helps to suppress the accumulation of body fat but also helps to degrade accumulated fats. Lee et al. (2012a) reported that white balloon flower (Platycodon grandiflorum for. albiflorum (Honda) $\mathrm{H}$. Hara) extracts ameliorates obesity and insulin resistance in obese mice via the activation of AMPK/ACC pathways and reductions of adipocyte differentiation. Zhao et al. (2005) reported Saponin rich fraction from BF reduce the serum TG and LDL-cholesterol, hepatic TG, the liver surface fat pads and remarkable reduction in calorie intake and however increased fecal TG excretion 2.1-3.2 folds, in dose depending manner.

Anyhow, Obesity's contribution to type 2 diabetes might be due to dysregulation of adipokines and glucose uptake. Ahn et al. (2012) reported BF extracts on adipokines and glucose uptake. $80 \%$ ethanol extract of BF markedly attenuated food intake, body weight, epididymal fat weight, adipocyte size and blood glucose levels by the oral glucose tolerance test in mice, and maintained serum levels of adiponectin, resistin, leptin, fructosamine and triglycerides. Gene expression analysis revealed that PGE up-regulated adiponectin, and down-regulated TNF- $a$ and leptin in fat tissue. In L6 muscle cells in vitro, PGE increased insulin-stimulated glucose uptake.

Hwang et al. (2013) investigate that PD can regulate hepatic lipogenesis via an AMPK-dependent signalling pathway. Lee et al. (2011a) reported that PD inhibits adipogenesis by modulating the WNT/ $\beta$-catenin pathway, Lee et al. (2012b) reported that molecular mechanism of PD to decrease the expression of adipogenic factors through AMP-activated protein kinase a (AMPKa) in adipocytes and its ability to 
prevent abdominal fat accumulation. PD significantly reduced fat accumulation by inhibiting adipogenic signal transcriptional factors, consequently, lipid metabolism was improved by increasing AMPKa,reduced PPAR $\gamma 2$ and C/EBPa expression in adipose tissue.

$\mathrm{Wu}$ et al. (2012) examined the effects of PD, on human umbilical vein endothelial cells (HUVECs) in vitro. PD increased $\mathrm{NO}$ concentration and decreased MDA level induced by oxLDL in the medium of endothelial cells. Moreover, PD significantly inhibited the oxLDL-induced increase in monocyte adhesion to endothelial cells as well as decreasing mRNA expression levels of VCAM-1 and ICAM-1 on these cells. These result shows PD has an anti-atherosclerotic activity.

\section{Antidiabetic Effects}

Triterpene saponins with inhibitory activity of glucose absorption may also be used for the prevention and treatment of diabetes. Oleanolic acid glycosides were found to have neither insulin-like nor insulin-releasing activity, but they inhibited gastric emptying and glucose-uptake in the small intestine. Investigation of the mode of action revealed that the inhibition of gastric emptying was mediated by capsaicin-sensitive sensory nerves and the central nervous system. Furthermore, oleanolic acid glycosides were suggested to suppress the gastric emptying by stimulating the release and/or production of dopamine to act through dopamine 2 receptors, which in turn causes the release of prostaglandins (Yoshikawa and Matsuda 2000).

Zheng et al. (2007) reported that BF may exert its hypoglycemic action by mechanisms such as inhibition of endogenous glucose production without stimulating insulin secretion (Table 2). Crude saponin of BF alleviated diabetic symptoms and improves glucose homeostasis by enhancing hepatic insulin sensitivity as a consequence of decreasing body fat storage, hepatic insulin resistance and improving insulin signalling, glucose-stimulated insulin secretion from pancreatic $\beta$-cells in a mild and non-obese type 2 diabetic animal model, 90\% pancreatectomized (Px) diabetic rats, fed a high-fat $\operatorname{diet}($ Kwon et al., 2009). Kwon et al. (2012) reported that Platyconic acid (PA) most effectively increased insulin-
Table 3. Blood glucose levels after once a day of BFE for 4 weeks in normal and STZ diabetic mice $(n=10)$ (Zheng et al., 2007).

\begin{tabular}{lccc}
\hline \multirow{2}{*}{ Groups } & \multicolumn{3}{c}{ Blood glucose(mg/dL) } \\
\cline { 2 - 4 } & Week 0 & Week 2 & Week 4 \\
\hline Normal & $104 \pm 11$ & $119 \pm 12$ & $125 \pm 15$ \\
STZ Contol & $360 \pm 28$ & $385 \pm 32$ & $410 \pm 35$ \\
STZ+150mg/kg BFE & $351 \pm 29$ & $311 \pm 29$ & $259 \pm 32^{* *}$ \\
STZ+300mg/kg BFE & $352 \pm 31$ & $302 \pm 33^{*}$ & $226 \pm 22^{* *}$ \\
STZ+Glibenclamide & $366 \pm 31$ & $305 \pm 32^{*}$ & $234 \pm 23^{* *}$ \\
\hline
\end{tabular}

${ }^{*} P<0.05,{ }^{* *} P<0.01$, significantly different from STZ controlmice.

stimulated glucose uptake in 3T3-L1 adipocytes, possibly in part by working as a peroxisome proliferator-activated receptors (PPAR)- $\gamma$ activator; however, none of the saponins improved glucose-stimulated insulin secretion in insulinoma cells. PA-treated diabetic mice exhibited the lowest peak serum glucose levels and highest serum insulin levels during the first part of OGTT. PA also improved insulin sensitivity: PA increased glycogen accumulation and decreased triacylglycerol storage in liver, which was associated with enhanced hepatic insulin signaling, while PA potentiated the expression of adiponectin and PPAR- $\gamma$ in adipose tissue, and improved insulin signaling and increased GLUT4 translocation into the membranes.

\section{Antidemantia Effects}

Since the pathology of dematantia is complex, it is too simplistic to assume that antioxidant treatment alone might alleviate or delay cognitive decline in dementia (Williams et al., 2011). Ethanol extract BF improve the cognitive deficit caused by scopolamine and that these effects might be due to BF mediated by inhibition of AChE activity and inhibition of TBARS (Moon et al., 2010). Kim et al. (2004) reported that the total $\mathrm{MeOH}$ extract and those with saponin rich fraction ameliorated cogntitive impairment but non-saponin fraction didn't. Choi et al. (2008a) reported that the mice with repeated administration of the root extract of $\mathrm{BF}$, crude saponin fraction and platycoside $\mathrm{E}$, showed a markedly prolonged step-through latency period (STL) on the passive avoidance task performed inducing acute ethanol intoxication in mice. These results suggested that the whole root extract of $\mathrm{BF}$ and its saponin platycoside E rather than the PD had an ameliorating effect on 


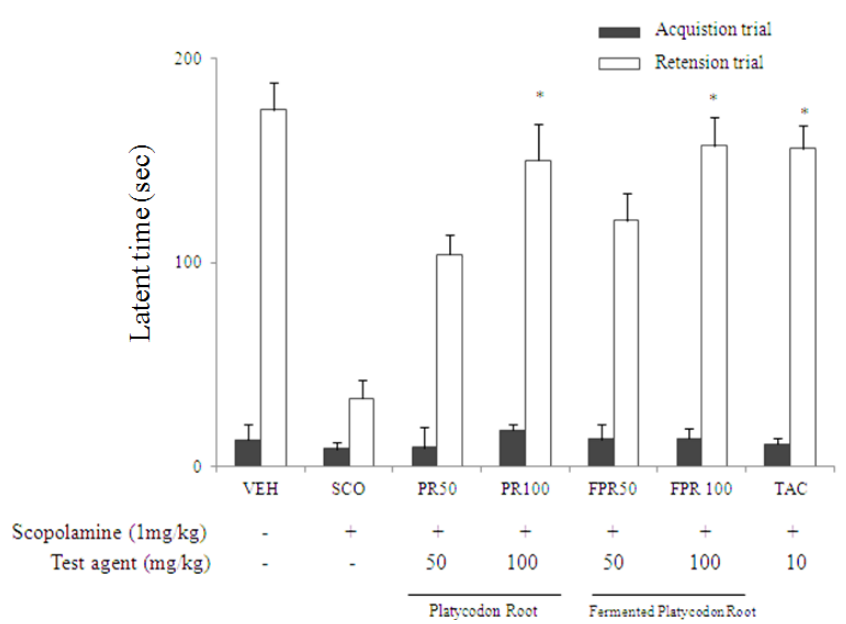

Fig. 6. Inhibitory effects of platycodon root (PR), fermented platycodon root (FPR) extract on scopolamine-induced memory impairment in mice in the passive avoidance test. mice were orally administrated PR, FPR 50, 100 ; TAC, tacrine $(10 \mathrm{mg} / \mathrm{kg})$ all values are means \pm S.D. $(n=6)$ *Significantly different from the control group ( $\left.{ }^{*} \mathrm{P}<0.05\right)$ (Kim et. al., 2013).

the ethanol-induced cognitive dysfunction in mice. Kim and Shin (2013) reported that $80 \%$ Ethanol extract of fermented BF with Saccharomyces cerevisae C-2 showed significant anti-amnestic and cognitive-enhancing activities related to the memory processes(Fig. 6).

\section{Anticancer Effects}

Due to the great variability of their structures, saponins always display anti-tumorigenic effects through varieties of antitumor pathways (Man et al., 2010). Saponins derived from BF may suppress tumor invasion and migration by inhibiting MMP-2 and MMP-9 activation (Lee et al., 2008). PD can significantly inhibit the proliferation, migration, invasion, or xenograft growth of various human tumor cell lines, including lung, ovary, melanoma, colon (Kim et al., 2005), breast (Chun and Kim, 2013b), liver (Qin et al., 2014), leukemia (Kim et al., 2008; Shin et al., 2009), gastric cancer cells (Chun et al., 2013a) etc. The molecular mechanisms responsible for the anticancer activity of PD involve the suppression of Akt and MAPK pathways (Chun and Kim, 2013; Qin et al., 2014), Its exposure induced apoptosis through caspase-3 dependent PARP, lamin A cleavage induced through Egr-1 activation (Shin et al., 2009). The primary antileukemia activity is induction of endoreduplication and mitotic arrest, as a consequence of suppressing spindle MT dynamics and promoting apoptosis in human leukemia cells (Kim 2008). Furthermore, it has direct cytotoxic effect on human leukemia cells and suppresses telomerase activity through transcriptional and post-translational suppression of hTERT (Dastager et al., 2008). Luan et al. (2014) shows a molecular mechanism of antiangiogenic activity of platycodon root, important hallmark in cancer development. Especially, PD inhibits HUVEC proliferation, motility, migration and tube formation. and it also inhibits the phosphorylation of VEGFR2 and downstream kinases in HUVEC. Chun et al. (2013c) survey on correlation of the chemical structure of $\mathrm{BF}$ and anti-proliferative effects on the seven types of cancer cell lines, PD, 2"- O-acetylplatycodin D, 3"-O-acetylplatycodin D, polygalacin D, 2"-O-acetyl polygalacin $\mathrm{D}$, and $3^{\prime \prime}$-O-acetylpolygalacin $\mathrm{D}$, isolated from $\mathrm{BF}$, and prosapogenins which lack the $\mathrm{C}-3$ or $\mathrm{C}-28$ sugar residues, have antiproliferative activity, and the presence of sugar residues, an O-acetyl group on the rhamnose, and a methyl group at C-4 contributes to their cytotoxicity and apoptotic activity.

\section{Toxicity}

There are two well-known adverse effects of saponins when overdose are hemolytic action and nauseant effect especially platycodin stimulated the vomiting center in anmals, crude platycodin was shown to have an inhibitory action on the central nervous system in the animal in the oral dosage range of $50-200 \mathrm{mg} / \mathrm{kg}$ (Takagi and Lee, 1972) In humans, there is a potential for some negative effects of excessive intake of saponins, including local effects on gut mucosa and secondary effects produced by mineral interactions decreasing availability for absorption (Milgate and Roberts, 1995).

A dose-dependent effect of PD on the sperm motility and viability was reported ( $\mathrm{Lu}$ et al., 2013). The maximum spermicidal effect was observed with a $0.25 \mathrm{mM}$ concentration of PD. More than $70 \%$ of the PD-treated sperm lost their HOS responsiveness at a concentration of $0.20 \mathrm{mM} \mathrm{PD}$, indicating that PD caused injury to the sperm plasma membrane. PD induced significant damage to both the head and tail membranes of the sperm. And also decreased the fertility to zero in rats, it was non-DNA damaging and not harmful to the 
vaginal tissue in the rats.

Lee et al. (2011b) reported that Single Oral Dose Toxicity Test of PD. After administration, the slight congestion of lung, atrophy of thymus, cyst in kidney, spleen atrophy or hypertrophy, and hypertrophy and focal hemorrhage of popliteal lymph node detected in the present study as gross findings, and hypertrophy of lung alveolus wall with focal hemorrhages, decreases of lymphoid cells in the cortex of thymus and red pulps of spleen, focal inflammatory cell infiltration in liver, edematous changes on the uterus, and hyperplasia of lymphoid cells in the popliteal lymph node detected as histopathological findings were considered as accidental findings related to the PD treatment. However, approximate $\mathrm{LD}_{50}$ of $\mathrm{PD}$ were considered over 2000 $\mathrm{mg} / \mathrm{kg}$, and is likely to be safe in humans.

\section{Discussion}

Traditionally BF root is used for cough suppressant and expectorant for cough, sore throat in folk medicine. But current research trend of $\mathrm{BF}$ is evaluate its medicinal effect of antiallergy, neuroprotective, anti-inflammatory, anti-obesity, antidiabetic and anti-cancer properties. BF modulate immune system by increase level of the immunosuppressive cytokine and finally improve asthma symptoms, BF not only helps to suppress the accumulation of body fat, but also helps to degrade accumulated fats, and also prevent abdominal fat accumulation. Saponin of BF alleviated diabetic symptoms and improves glucose homeostasis and decreasing body fat storage, hepatic insulin resistance and improving insulin signalling. These result may indicate that lifestyle-related diseases due to lack of exercise. And one thing we should pay attention to $\mathrm{BF}$ is it can be administrated a long period, regardless of the form of food or drugs. For this reason, consumer's demand are increased and also they want proof of cultivate year of BF and producing country. In Korean market, there are high demand in BF with white petals, as noted above, Korean native $\mathrm{BF}$ have lower contents of $\mathrm{PD}$, but greater diversity on platycodin since saponin component with relatively large polarity is much more than Chinese BF. Saponin with large polarity is need to metabolite to increase bioavailability, and elucidate various efficacy via metablote or heat processing in needed. $\mathrm{PD}$, rich in a $\mathrm{BF}$ with blue petal, is mainly focused on cancer research so far, However, with Korean domestic BF, research on cholesterol lowering effect and anti allergic effect is mainly reported in recent year. Judging from the research trend of up to now, more research on memory improvement effects of PD is needed in the future. And besides Root, elucidate efficacy of the flower and aerial parts, rich in a phenolic compounds, are need in the future.

\section{References}

Abdollahi, M. and B. Afshar-Imani. 2003. A review on obesity and weight loss measures. Middle East Pharmacy 11:6-10.

Ahn, M.J., J.Y.Bae, and J.H. Park. 2011. Pharmacognostical studies of the 'Gil Gyung'. Kor. J. Pharmacogn 42(3):213-217.

Ahn, Y.M., S.K. Kim, J.S. Kang, and L.C. Lee. 2012. Platycodon grandiflorum modifies adipokines and the glucose uptake in high-fat diet in mice and L6 muscle cells. J. Pharmacy and Pharmacology, 64:697-704.

Boo, H.O., J.H. Shin, Y.S. Kim, H.J. Park, H.H. Kim, S.J. Kwon, and S.H. Woo. 2013. Comparative antioxidant enzyme activity of diploid and tetraploid Platycodon grandiflorum by different drying methods. Korean J. Plant Res. 26(3):389-396.

Cha, M.R., C.W. Choi, D.S. Yoo, Y.H. Choi, B.K. Park, E.J. Kim, Y.S. Kim, J.S. Kang, Y.H. Kim, and S.Y Ryu. 2011. Cognitive enhancing effect of saponin rich fraction from the roots extract of Platycodon grandiflorum in mice. Kor. J. Pharmacogn. 42(1):27 $-31$.

Choi, J.H., E.H. Han, B.H. Park, H.G. Kim, Y.P. Hwang, Y.C. Chung, Y.C. Lee, and H.G. Jeong. 2012. Platycodi Radix suppresses development of atopic dermatitis-like skin lesions Environ Toxicol Pharmacol. 33(3):446-452.

Choi, J.H., Y.P. Hwang, H.S. Lee, and H.G Jeong. 2009. Inhibitory effect of Platycodi Radix on ovalbumin-induced airway inflammation in a murine model of asthma. Food and Chemical Toxicology. 47(6):1272-1279.

Choi, Y.H., Y.S. Kim, S.J. Yeo, S.H. Roh, Y.C. Jeong, J.S. Kang, and S.Y. Ryu. 2008a. Ameliorating effect of balloon flower saponin on the ethanol-induced memory impairment in mice. Phytother. Res. 22:973-976.

Choi, Y.H, D.S. Yoo, C.W. Choi, M.R. Cha, Y.S. Kim, H.S. Lee, K.R. Lee, and S.Y. Ryu. 2008b. Platyconic acid a, a genuine triterpenoid saponin from the roots of Platycodon grandiflorum. Molecules 13:2871-2879.

Chun, J., E.J. Joo, M. Kang, and Y.S. Kim. 2013a. Platycodin D induces anoikis and caspase-mediated apoptosis via p38 MAPK in AGS human gastric cancer cells. J Cell Biochem. 14(2): 456-470

Chun, J. and Y.S. Kim. 2013b. Platycodin D inhibits migration, invasion, and growth of MDA-MB-231 human breast cancer cells 
via suppression of EGFR-mediated Akt and MAPK pathways. Chem. Biol. Interact. 205:212-221.

Chun, J.M., I.J. HA, and Y.S. Kim. 2013c. Antiproliferative and apoptotic activities of triterpenoid saponins from the roots of Platycodon grandiflorum and their structure-activity relationships. Planta Med. 79:639-645.

Chung, M.J., S.H. Kim, J.W. Park, Y.J. Lee, S.S. Ham. 2012. Platycodon grandiflorum root attenuates vascular endothelial cell injury by oxidized low-density lipoprotein and prevents high-fat diet-induced dyslipidemia in mice by up-regulating antioxidant proteins. Nutr Res. 32(5):365-373.

Dastager, S.G, J.C. Lee, Y.J. Ju, D.J. Park, and C.J. Kim. 2008. Microbacterium kribbense sp. nov., isolated from soil. Int J Syst Evol Microbiol. 58:2536-2540.

Ha, I.J., Y.W. Ha, M. Kang, J. Lee, D. Park, and Y.S.Kim. 2010. Enzymatic transformation of platycosides and one-step separation of platycodin D by high-speed countercurrent chromatography. J Sep. Sci. 33:1916-1922.

Ha, M.A., J.W. Kim, S.W. Lee, H.S. Chun, Y.S. Cho, and Y.W. Shin. 2014. Anti-pruritic effect of ethanol extracts from Platycodon grandiflorum and its fermented production in scratching behavior mouse models. Kor. J. Herbology. 29(6): 155-163.

Ha,Y.W., Y.C. Na, J.J. Seo, S.N. Kim, R.J. Linhardt, and Y.S. Kim. 2006. Qualitative and quantitative determination of ten major saponins in Platycodi Radix by high performance liquid chromatography with evaporative light scattering detection and mass spectrometry. J. Chromatography 1135(1):27-35.

Han, E.H., Y.W. Son, M.B. Kim, Y.W. Shin, Y.S. Cho, and S.W. Lee. 2014. Establishment of tissue culture and acclimation of white balloon flower (Platycodon grandiflorum DC. cv. Jangback) for the raising of in vitro propagated seedlings. J Plant Biotechnol. 41:134-139.

Han, L.K., Y.N. Zheng, B.J. Xu, H. Okuda, and Y. Kimura. 2002. Saponins from Platycodi Radix ameliorate high fat diet? induced obesity in mice. J Nutr. 132(8):2241-2245.

Han, L.K., B.J. Xu, Y. Kimura, Y.N. Zheng, and H. Okuda. 2000. Platycodi Radix affects lipid metabolism in mice with high fat diet ${ }^{-}$ induced obesity. J. Nutr. 30(11):2760-2764.

Han, S.B., S.H. Park, K.H. Lee, C.W. Lee, S.H. Lee, H.C. Kim, Y.S. Kim, H.S. Lee, and H.M. Kim. 2011. Polysaccharide isolated from the radix of Platycodon grandiflorum selectively activates $\mathrm{B}$ cells and macrophages but not $\mathrm{T}$ cells. Int. Immunopharmacol. 1:1969-1978.

Hwang, C.R, S.H. Oh, H.Y. Kim, S.H. Lee, I.G. Hwang, Y.S. Shin, J.S. Lee, and H.S. Jeong. 2011. Chemical composition and antioxidant activity of Deoduk (Codonopsis lanceolata) and Doragi (Platycodon grandiflorum) according to temperature. J. Korean Soc. Food Sci. Nutr. 40:798-803.

Hwang, Y.P., J.H. Choi, H.G. Kim, T. Khanal, G.Y. Song, M.S. Nam, H.S. Lee, Y.C. Chung, Y.C. Lee, and H.G. Jeong. 2013. Saponins, especially platycodin $\mathrm{D}$, from Platycodon grandiflorum modulate hepatic lipogenesis in high-fat diet-fed rats and high glucoseexposed HepG2 cells. Toxicology and Applied Pharmacology
267:174-183.

Jang, D.S, Y.M. Lee, I.H. Jeong, and J.S. Kim. 2010. Constituents of the flowers of Platycodon grandiflorum with inhibitory activity on advanced glycation end products and rat lens aldose reductase in vitro. Arch Pharm Res 33:875-880.

Jeong, C.H, G.N. Choi, J.H. Kim, J.H. Kwak, D.O. Kim, Y.J. Kim, and H.J. Hoe. 2010. Antioxidant activities of the aerial parts of Platycodon grandiflorum. Food Chem. 118:278-282.

Kasamatsu, S., A. Hachiya, Y. Shimotoyodome, A. Kameyama, Y. Miyauchi, K. Higuchi, T. Fujimori, A. Ohuchi, Y. Shibuya, and T. Kitahara. 2014. The inhibitory effect of a platycodon root extract on ultraviolet B-induced pigmentation due to a decrease in Kit expression. J. Nat. Med. 68:643 -646.

Korkina, L.G. 2007. Phenylpropanoids as naturally occurring antioxidants: from plant defense to human health. Cell Mol. Bio. 53(1):15-25.

Kim, H.J. and Y.S. Cho. 2011. Characteristics of rhizome rot incidence of Platycodon grandiflorus by ridge width and depth and cultivation period in the seeding place. korean J. Medicinal Crop Sci. 19(4): 246-250.

Kim, H.K., J.S. Choi, D.S. Yoo, Y.H. Choi, G.H. Yon, K.S. Hong, B.H. Lee, H.J. Kim, E.J. Kim, B.K. Park, Y.C. Jeong, Y.S. Kim, and S.Y. Ryu 2007. HPLC analysis of saponins in Platycodi Radix. Kor J. Pharmacognosy 38(2):192-196.

Kim, M.O., D.O. Moon, Y.H. Choi, J.D. Lee, N.D. Kim, and G.Y. Kim. 2008. Platycodin D induces mitotic arrest in vitro, leading to endoreduplication, inhibition of proliferation and apoptosis in leukemia cells. Int. J. Cancer. 122:2674-2681.

Kim, M.S., W.G. Kim, H.S. Chung, B.W. Park, K.S. Ahn, J.J. Kim, and H. Bae. 2012. Improvement of atopic dermatitis-like skin lesions by platycodon grandiflorum fermented by Lactobacillus plantarum in NC/Nga Mice. Biol. Pharm. Bull. 35:1222-1229.

Kim, S.D., J.H. Do, and H.I. Oh. 1981. Antioxidant activity of Panax ginseng browning products. J. Korean Agric. Chem. Soc. 24:161166.

Kim, T.W., S.J. Lee, M.B. Kim, C.G. Park, Y.W. Shin, Y.S. Cho, and S.W. Lee. 2014. Differentiation of indigenous balloon flower (Platycodon grandiflorum DC.) germ lines in South Korea by using RAPD analyses. J. Plant Biotechnol. 41:19-25.

Kim, T.Y. and Y.W. Shin. 2013. The effect of femented Platycodon grandiflorum on the memory impairment of mice. Kor. J. Herbology 28(2):25-31.

Kim, Y.P., E.B. Lee, S.Y. Kim, D. Li, H.S. Ban, S.S. Lim, K.H. Shin, and K. Ohuchi. 2001. Inhibition of prostaglandin e2 production by platycodin d isolated from the root of Platycodon grandiflorum. Planta Med. 67:362-364.

Kim, Y.S., J.S. Kim, Y.H. Choi, J.H. Seo, J.W. Lee, S.K. Kim, J.S. Kang, H.S. Lee, Y.S. Cho, S.H. Roh, Y.C. Jeong, K.W. Shim, and S.Y. Ryu. 2004. ameliorating effect of the root extract from Platycodon grandiflorum on the ethanol-induced cognivie impairment in mice. Kor. J. Pharmacogn. 35(3):239-243.

Kim, Y.S, J.S. Kim, S.U. Choi, J.S. Kim, H.S. Lee, S.H. Roh, Y.C. Jeong, Y.K. Kim, and S.Y. Ryu. 2005. Isolation of a new saponin 
and cytotoxic effect of saponins from the root of Platycodon grandiflorum on human tumor cell lines. Planta Med. 71:566-568.

Kwon, D.Y., Y.S. Kim, S.M. Hong, and S. Park. 2009. Long-term consumption of saponins derived from Platycodi radix (22 years old) enhances hepatic insulin sensitivity and glucose-stimulated insulin secretion in $90 \%$ pancreatectomized diabetic rats fed a high-fat diet. British Journal of Nutrition 101:358-366.

Kwon, D.Y., Y.S. Kim, S.Y. Ryu, Y.H. Choi, M.R. Cha, H.J. Yang, and S. Park. 2012. Platyconic acid, a saponin from Platycodi radix, improves glucose homeostasis by enhancing insulin sensitivity in vitro and in vivo. Eur. J. Nutr. 51:529-540.

Lee, B.J., D.H. Kim, C.H. Lee, S.W. Lee, H.S. Chun, S.H. Jeon, D. Son, and Y.S .Cho. 2013a. Effects of pre-seeding treatment on seed germination of Platycodon grandiflorum. Korean J. Intl. Agri. 25:423-427.

Lee, B.J, Y.W. Shin, S.W. Lee, H.S. Chun and Y.S. Cho. 2014a. Effects of storage methods and periods on root hardness and content of saponin in Platycodon grandiflorum Radix. Korean J. Crop Sci. 59:134-138.

Lee, C.E., H.J. Hur, J.T. Hwang, M.J. Sung, H.J Yang, H.J. Kim, J.H. Park, D.Y. Kwon, and M.S. Kim. 2012a. Long-Term consumption of Platycodi Radix ameliorates obesity and insulin resistance via the activation of AMPK Pathways. Evidence-Based Complementary and Alternative Medicine. 759143: 1-11.

Lee, C.H., S.W. Lee, and H. Lee. 2010. Change of soil chemical properties according to cultivation area and cultural year for Platycodon grandiflorum. Korean J. Medicinal Crop Sci. 18:273279.

Lee, E.J., M.S. Kang, and Y.S. Kim. 2012b. Platycodin D inhibits lipogenesis through AMPKa- PPAR $\gamma 2$ in 3T3-L1 cells and modulates fat accumulation in obese mice. Planta Med. 78:15361542.

Lee, H.Y., S.M. Bae, Y.S. Kim, and Y.S. Yoon. 2011a. WNT/ß -catenin pathway mediates the anti-adipogenic effect of platycodin $\mathrm{D}$, a natural compound found in Platycodon grandiflorum. Life Science 89:388-394.

Lee, J.Y., W.I. Hwang, and S.T. Lim. 2004a. Antioxidant and anticancer activities of organic extracts from Platycodon grandiflorum A. De Candolle roots. J. Ethnopharmacol. 93:409415.

Lee, JY, J.W. Yoon, C.T. Kim, and S.T. Lim. 2004b. Antioxidant activity of phenylpropanoid esters isolated and identified from Platycodon grandiflorum A. DC. Phytochemistry 65:3033-3039.

Lee, K.J, S.J. Hwang, J.H. Choi, H.G. Jeong. 2008. Saponins derived from the roots of Platycodon grandiflorum inhibit HT-1080 cell invasion and MMPs activities: regulation of NF-kappaB activation via ROS signal pathway. Cancer Lett. 268:233-243.

Lee, S.H, E.M. Song, G.Y. Jang, M. Li. M.Y. Kim, H.J. Park, T.S. Kang, and H.S. Jeong. 2013b. Physicochemical characteristics and antioxidant activities of doragi (Platycodon grandiflorum) at different aging temperatures and for various durations. J. Korean Soc. Food Sci. Nutr. 42:1405-1411.

Lee, S.J., W.S. Bang, J.Y. Hong, O.J. Kwon, S.R. Hin and K.Y. Yoon. 2013c. Antioxidant and antimicrobial activities of black doraji (Platycodon grandiflorum) Korean J. Food Preserv. 20:510-517.

Lee, SJ, S.R. Shin, and K.Y. Yoon. 2013d. Physicochemical properties of black doraji (Platycodon grandiflorum) Korean J. Food Sci. Technol. 45:422-427.

Lee, S.T., J.S. Ryu, M.B. Kim, D.K. Kim, H.J. Lee, and J.S. Heo. 1999. Crude saponin contents of Platycodon grandiflorum(Jacq.) A.DC. Kor J. Medicinal Crop Sci 7:172-176.

Lee, S.W., Y.W. Son, Y.W. Shin, and Y.S. Cho. 2014b. The current status in korea and future perspectives of balloon flower (Platycodon grandiflorum) in gyeongsangnam-do. Korean J. Int. Agric. 26(1):68-72.

Lee, W.H., C.O. Gam, S.K. Ku, and S.H. Choi. 2011b. single oral dose toxicity test of platycodin d, a saponin from platycodin radix in mice. Toxicol. Res. 27(4):217-224.

Lee, YH, J.G. Kim, S.R. Park, Y.J. Choi, S.J. Cho, and H.D. Yun. 2000. Rhizome Rot incidence of Platycodon grangiflorus as Influenced by the soil chemical properties and microbial flora. Korean Journal of Environmental Agriculture 19:62-66.

Lee, Y.J., H.O. Lee, J.Y. Kim, K.H. Kwon, H.S. Cha, and B.S. Kim. 2011c. Quality characteristics of frozen doraji (Platycodon grandiflorum) according to various blanching treatment conditions. Korean J. Food Preserv. 18:661-668.

Lu, Z., L. Wang, R. Zhou, Y. Qiu, L. Yang, C. Zhang, M. Cai, M. Mi, and H. Xu 2013. Evaluation of the spermicidal and contraceptive activity of platycodin d, a saponin from Platycodon grandiflorum. PLoS One. 8 (11) e82068.

Luan, X., Y.G. Gao, Y.Y. Guan, J.R. Xu, Q. Lu, M. Zhao, Y.R. Liu, H.J. Liu, C. Fang, and H.Z. Chen. 2014. Platycodin D inhibits tumor growth by antiangiogenic activity via blocking VEGFR2mediated signaling pathway. Toxicol. Appl. Pharmacol. 281: 118-124.

Man, S., W. Gao, Y. Zhang, L. Huang, and C. Liu. 2010. Chemical study and medical application of saponins as anti-cancer agents Fitoterapia. 81(7): 703-714.

Milgate, J. and D.C.K. Roberts. 1995. The nutritional and biological significance of saponins. Nutrition Research 15(8):1223-1249.

Moon, M.K., J.Y. Ahn, S. Kim, S.Y. Ryu, Y.S. Kim, and T.Y. Ha. 2010. Ethanol extract and saponin of Platycodon grandiflorum ameliorate scopolamine- induced amnesia in mice. J. Med. Food. 13(3): 584-588.

Oda, K., H. Matsuda, T. Murakami, S. Katayama, T. Ohgitani, and M. Yoshikawa. 2000. Adjuvant and haemolytic activities of 47 saponins derived from medicinal and food plants. Biol. Chem. 381(1):67-74.

Oh, Y.C., O.H. Kang, J.G. Choi, Y.S. Lee, O.O. Brice, H.J. Jung, S.H. Hong, Y.M. Lee, D.W. Shin, Y.S. Kim, and D.Y. Kwon. 2010. anti-allergic activity of a platycodon root ethanol extract. Int. J. Mol. Sci. 11:2746-2758.

Park, C.G., S.C. Lee, G.S. Kim, J.S. Sung, D.H. Kim, C.B. Park, and J.H. Lee. 2010a. Agronomic characteristics of Platycodon grandiflorum (Jacq.) A.DC. collected from East-Asia. Korean J. Intl. Agri. 22(2):158-163. 
Park, C.G., Z.Y. Yan, S.C. Lee, T.K. Shon, H.W. Park, and D.C. Jin. 2005. Genetical Diversity and DNA polymorphism in Platycodon grandiflorum DC. collected from east-asian area. Korean J. Medicinal Crop Sci. 13(2):115-120.

Park J.H., J.M. Lee, C.H. Lee, J.H. Cho, J.B. Jang, and K.S. Lee. 2010 b. Enhancing the immunogenicity of Platycodon Grandiflorum on adaptive immune system. J. of Oriental Obestrics \& Gynecology 23(4) :1-9.

Park, S.J., A.Y. Kim, H.S. Lee, B.Y. Kim, and M.Y. Baik. 2012a. Effects of puffing process on the saponin components in Platycodon grandiflorus (jacqin) A.De Candle. Food Engineering Progress 16(2):164-171.

Park, S.J., H.A. Lee, J.W. Kim, B.S. Lee, and E.J. Kim. 2012b. Platycodon grandiflorus alleviates DNCB-induced atopy-like dermatitis in NC/Nga mice. Indian J Pharmacol. 44(4):469-474.

Park, Y.S., Y. Yoon, and H.S. Ahn. 2007. Platycodon grandiflorum extract represses up-regulated adipocyte fatty acid binding protein triggered by a high fat feeding in obese rats. World J. Gastroenterol. 13(25):3493-3499.

Qin, H, Du X, D.Y. Zhang, and R. Wang. 2014. Platycodin D, a triterpenoid saponin from Platycodon grandiflorum, induces G2/M arrest and apoptosis in human hepatoma HepG2 cells by modulating the PI3K/Akt pathway. Tumour Biol. 35:1267-1274.

Rao, A.V. and D.M. Gurfinkel. 2000. The bioactivity of saponins: triterpenoid and steroidal glycosides. Drug Metabol Drug Interact. 17(1-4):211-235.

Ryu, HS. 2014. Effects of water extract from Platycodon grandiflorum on mouse immune cell activation ex vivo by oral administration. Korean J. Food \& Nutr. 27(1):99-104.

Saeki, T, K. Koike, and T. Nikaido. 1999. A compartive study on commercial, botanical gardens and wild samples of the root of Platycodon grandiflorum by HPLC analysis. Planta Med. 65: 428-431.

Saeki, T. and T. Nikaido. 2003. Evaluations of saponin properties of HPLC analysis of Platycodon grandiflorum A.DC. Yakugaku Zasshi. 123(6): 431-441.

Shin D.Y, G.Y. Kim, W. Li, B.T. Choi, N.D. Kim, H.S. Kang, and Y.H. Choi. 2009. Implication of intracellular ROS formation, caspase-3 activation and Egr-1 induction in platycodon D-induced apoptosis of U937 human leukemia cells. Biomedicine \& Pharmacotherapy 63:86-94.

Shin, J.S. and B.S. Kang. 1992. A Study on the difference of saponin contents among radix platycodi types. The Korean Journal of Oriental Medical Prescription 3(1):163-196.

Son, I.H., Y.H. Park, S.I. Lee, H.D. Yang, and H.I. Moon. 2007. Neuroprotective activity of triterpenoid saponins from Platycodi radix against glutamate-induced toxicity in primary cultured rat cortical cells. Molecules 12:1147-1152.

Seong, J.D., G.S. Kim, H.T. Kim, C.B. Park, and S.M. Kim. 2004. Effect of split application of nitrogen fertilizer on growth and yield in Platycodon grandiflorum A. DC. Korean J. Medicinal Crop Sci. 12(6):437-441.

Takagi, K. and E.B. Lee. 1972. Phamarcological studies on
Platycodon grandiflorum A. DC I. acute toxicity and central depressant activity of crude platycodin. Yakugaku Zasshi 92(8):951-960.

Takechi, M. and Y.Tanaka. 1995. Haemolytic time course differences between steroid and triterpenoid saponins. Planta Med. 61:76-77.

Turkmen, N., F. Sari, and Y.S. Velioglu. 2005. The effects of cooking methods total phenolic and antioxidant activity of selected green vegetables. Food Chem. 93:713-718.

Wie, H.J., H.L. Zhao, J.H. Chang, Y.S. Kim, I.K. Hwang, and G.E. Ji. 2007. Enzymatic modification of saponins from Platycodon grandiflorum with Aspergillus niger. J. Agric. Food Chem. 55:8908 -8913.

Wu, J, G. Yang, W. Zhu, W. Wen, F. Zhang, J. Yuan, and L. An. 2012. Anti-atherosclerotic activity of platycodin d derived from roots of Platycodon grandiflorum in human endothelial cells. Biol. Pharm. Bull. 35(8):1216-1221.

Williams, P., A. Sorribas, and M.J. Howes. 2011. Natural products as a source of Alzheimer's drug leads. Nat. Prod. Rep. 28:48-77.

Xie Y, W. Deng, H. Sun, and D. Li. 2008. Platycodin D2 is a potential less hemolytic saponin adjuvant eliciting Th1 and Th2 immune responses. Int Immunopharmacol. 8:1143-1150.

Xu, B.J., L.K. Han, Y.N. Zheng, J.H. Lee, and C.K. Sung. 2005. In vitro inhibitory effect of triterpenoidal saponins from Platycodi Radix on pancreatic lipase. Arch. Pharm. Res. 28(2):180-185.

Yan, Y.Z, J.C. Xue, J.R. Wu, D.S. Yoo, S.Y. Lee, S.Y. Kim, M.R. Uddin, and S.U. Park. 2012. Variation of triterpenoid saponin contents in Platycodon grandiflorum (Jacq.) A.D.C. Asian Journal of Chemistry 24(3):1268-1270.

Yoo, D.S., Y.H.Choi, M.R. Cha, B.H. Lee, S.J. Kim, G.H. Yon, K.S Hong, Y.S. Jang, H.S. Lee, Y.S. Kim, S.Y. Ryu, and J.S. Kang. 2011. HPLC-ELSD analysis of 18 platycosides from balloon flower roots (Platycodi Radix) sourced from various regions in Korea and geographical clustering of the cultivation areas. Food Chemistry 129:645-651.

Yoshikawa, M. and H. Matsuda. 2000. Antidiabetogenic activity of oleanolic acid glycosides from medicinal food stuffs. Biofactors 13:231-237.

Zhao, H.L., K.H. Cho, Y.W. Ha, T.S. Jeong, W.S. Lee, Y.S. Kim. 2006. Cholesterol-lowering effect of platycodin D in hypercholesterolemic ICR mice. Eur. J. Pharmacol. 537:166-173.

Zhao, H.L., S.V. Harding, C.P. Marinangeli, Y.S. Kim, and P.J. Jones. 2008. Hypocholesterolemic and anti-obesity effects of saponins from Platycodon grandiflorum in hamsters fed atherogenic diets. J. Food Sci. 73(8):195-200.

Zhao, H.L. and Y.S Kim. 2004. Determination of the kinetic properties of platycodon D for the inhibition of pancreatic lipase using a 1,2-diglyceride-based colorimetric assay. Arch. Pharm. Res. 27(10):1048- 1052.

Zhao, H.L., J.S. Sim, S.H. Shim, Y.W. Ha, S.S. Kang, and Y.S. Kim. 2005. Antiobese and hypolipidemic effects of platycodin saponins in diet-induced obese rats: evidences for lipase inhibition and calorie intake restriction. Int. J. Obes. (Lond) 29(8):983-990. 
Zheng, J., J. He, B. Ji, Y. Li, and X. Zhang. 2007. Antihyperglycemic effects of Platycodon grandiflorum (Jacq.) A. DC. extract on streptozotocin-induced diabetic mice. Plant Foods Hum. Nutr. 62(1):7-11.

\section{VII. 적요}

도라지는 세계적으로 1속1종만 알려져 있는 식물로 관상용으로 도 가치가 있는 대표적인 약용 및 식용식물이다. 경상남도에서 제 정된 토종농산물 보존·육성에 관한 조례에 도라지가 포함되는 등 국내에 자생하는 토종 도라지에 관한 관심이 증대되고 있으며 여기 에 최근 국내 도라지 최대 수출국이던 중국의 자국 내 도라지 수요 증가로 수출물량의 감소로 인해 국내의 재배면적 및 생산량이 증가 하고 있는 추세에 있다. 이러한 추세에 발 맞춰 장백도라지의 대량 증식을 위한 조직배양 및 순화 조건, 도라지 재배로 인한 토양의 화 학적 특성변화, 뿌리 썩음 방제, 수확 후 저장 및 가공과정에 관한 연 구결과가 보고되고 있다. 한편, 국내산 토종도라지는 지표물질로 알려진 platycodin D 가 중국산에 비해 현저히 적다는 것이 다수의
연구결과에 의해 입증되고 있다. 하지만 기존 발표된 연구결과를 종합 해 볼 때 도라지의 다양한 약리작용을 platycodin D 가 대표하 지는 않는다는 점이 뒷받침 되므로 국내산 도라지의 고유성분에 대 한 연구와 이를 증가시킬 수 있는 재배방법 및 가공방법에 대한 체 계적인 연구가 시급한 실정이다. 따라서 본 고 에서는 도라지의 기 원, 재배, 가공, 효능에 대해 분야별로 최근 보고된 연구결과를 종합 하여 다음과 같이 국내도라지 연구에 대한 방향을 제안하고자 한 다. 첫째, 외래종에 비해 토종 도라지는 사포닌이 platycodin $\mathrm{D}$ 에 편중되지 않고 재배기간이 길어질수록, 측근이 발달할수록 극성이 큰 사포닌 생성이 되므로 이러한 사포닌에 대한 생체이용률을 높이 기 위해서는 발효 또는 가열처리에 대한 연구가 필요하다. 둘째, platycodin D가 항암연구에 집중되어 있다면 platycodin D 이외 의 국내산 도라지에 함유된 다양한 사포닌으로 콜레스테롤 감소효 과, 면역조절작용 및 기억력개선작용에 대한 연구가 필요하다. 셋 째, 도라지의 뿌리 이외에 지상부에 함유된 페놀성 화합물의 항산 화작용을 이용한 연구가 필요하다고 결론지을 수 있다. 